\title{
Different Theoretical Logic Study of Ethnomusicology and the Anthropology of Music
}

\author{
Linhan $\mathrm{Yu}^{1, \mathrm{a}}$ \\ ${ }^{1}$ Art Institute, Wenshan University, Wenshan, Yunnan, China, 663000 \\ ${ }^{a}$ email
}

\begin{abstract}
Keywords: Ethnomusicology, The Anthropology of Music, Theoretical Logic, National Philosophy, Discipline Methodology
\end{abstract}

\begin{abstract}
The Anthropology of Music and Ethnomusicology two research areas are interrelated in distinguished under the guidance of mathematical logic, along with the development and refinement of discipline nowadays. In the national philosophy and methodology subjects, this paper describes the difference of the Anthropology of Music and Ethnomusicology. This paper explains the different theoretical logic of the Ethnomusicology and the Anthropology of Music Fieldwork from a diachronic Synchronic discipline methodology.
\end{abstract}

\section{Introduction}

By researching the world various ethnic music, ethnomusicology identifies the various special laws folk music development throughout the world and universal law. The Anthropology of Music as a cultural phenomenon, to study human behavior and social attributes from the popular culture Phenomena. Just within sight range of the author, not found in academic circles for Ethnomusicology and The Anthropology of Music. On the field there is a clear and detailed combing their theoretical logic, resulting in between there are many problems to be solved. Among the most prominent is The Anthropology of Music and Ethnomusicology discipline problem definition. Today, there are two voices most apparent: a voice said: "In China, 'The Anthropology of Music' title can be regarded as a compromise name, it can be described as' Chinese Music ',' Chinese Ethnomusicology ',' music cultural anthropology ',' Music culture 'and' cultural Anthropology of Music 'is a comprehensive. " [1] Another Voice think: Ethnomusicology and 'The Anthropology of Music' is the same as in the study, but the research point of view, research methods and research purposes two different disciplines, not the same subject two different call. "[2] I think that in the academic diversity of today, both views have their own theoretical perspectives and practical base, but in order to further develop Academic Research musicology, from differences in theoretical logic to different dialysis Ethnomusicology and Music humans meaningful. This article attempts from Ethnomusicology and The Anthropology of Music national philosophy, discipline methodological level segregation Ethnomusicology and The Anthropology of Music school of mathematical logic, in order to Ethnomusicology and The Anthropology of Music Academic defined to be explored, for people to study Ethnomusicology and The Anthropology of Music provides a reference to research methods and focus mode.

\section{The National Philosophy Level}

Today, globalization has led the world fusion of diverse cultures, complementary, and Infiltrating association between cultures and ethnic groups. This fact has led to social and Ethnomusicology The Anthropology of Music in different research areas exhibit different internal relations. National is a historical category, has its occurrence, development and demise of the process. Academic understanding of the nation also eyes of the beholder, the wise see wisdom. Morgan Marx summary "Ancient Society" a book that: "when combined under one government tribal merge into a unified whole, the national tenor produce." [3] Nation is "a people in the history of the formation of a common language, common geography, common economic life and stable performance in the community on a common culture, a common psychological quality." [4] National on the date of its 
birth and country are inextricably linked. But imagine to national product by nationalism, not create a nation state and nationalism, but rather the creation of national and ethnic nationalism. [5] it is easy to see, not only with the nation both countries are inextricably linked, and in some ethnic and national perspective there is a certain relationship between the equivalent. From the perspective of ethnic characteristics, the nation refers to the evolutionary history of small to large human populations to the common ancestral background, and "the family" from generation to generation, "relative" and "blood" as the basis of ethnic groups. [6] It is not necessarily linked with the country. Set aside the ethnic and national ties universality, social, and pay more attention to the world's multi-cultural ties and identity universality. Philosophy is that people on the philosophy and fundamental philosophical problems associated with the fundamental views and opinions, so that the fundamental views and opinions epitomizes core concepts and basic ideas as a philosophical doctrine or philosophy has. In the author's view, the nation and discussed philosophy can be summarized as national philosophy contains two aspects. The first of the peoples and nations closely, emphasis on political and national units are congruent relationship. That is, the nation-state entity determines the orientation of Ethnic philosophy of the nation-state became the nation Thinking philosophy is an important latitude, [7] and then form a narrow understanding of philosophy nationalization mode. Second, put aside the national political units, forming a generally recognized ethnic group, of blood. This requires scholars to form a common sense of identity from the perspective of all mankind. Mr. Silk and Bamboo said: "Only the nation produces, as the nation's only music may constitute its unique music and other ethnic distinction (distinct) Nationality character." [8] In fact, the national philosophy under refraction, from the perspective of the paradigm of the nation-state and all humanity to study Ethnomusicology and the Anthropology of Music students without mathematical logic, so both research vision with the world but necessary.

National Ethnology is for the study subjects. It is the nation as a whole to conduct a comprehensive study national origin, development and extinction. Ethnomusicology not as a national study of folk music, like the Soviet musician explains, unlike earlier said the "I National Music" excluded only to study his nation's music. [9] Chinese scholars studying comparative musicology from the start to put a foothold on the nation-state of the conceptual system, in a global perspective to study their traditional music, folk music, music system, so that China's music system can develop in succession on the basis of the majority, from Wang Guangqi "Oriental ethnic music of" one article to boost the national spirit to a large collection, collation and study of religious music and folk music and other content for the music service, and then how to strengthen the world Ethnomusicology convergence. It characterized the Chinese Ethnomusicology studies.

If Ethnomusicology Musicology and Ethnology is a combination of interdisciplinary social sciences, then The Anthropology of Music is also a music and anthropology combining sociological interdisciplinary. The Anthropology of Music from the relationship between music and culture to explore human interaction, behavior and musical expression between ideological roots also studied music phenomenon and its behavior contributed to the music as a culture to reveal its human existence, value and significance of production and life arising from [10], which is the theoretical logic of musicology. With the diversity and complexity of world music elements, twenties of the twentieth century, Boas and his students Melville J. Herkovits proposed a "cultural relativism" thought in practice anthropology, people think that culture is the sum of the habits and thought patterns of a particular society, each nation has its intergenerational values. Because every culture is an independent systems, traditions and value systems of different cultures is beyond comparison, every culture only by its own standards and values to be judged. Every culture has its reasons for existence without separately from the merits and, with full respect for different cultures, not in their own cultural standards to judge and evaluate. In the author's opinion, The Anthropology of Music aside the countries in the political framework, the research perspective implanted to all ethnic groups in the world and with the thought Boas broke "my family ethnocentricity" fetters, so between regions and cultural groups not because of geography, language, race and lead to isolation between different cultures can not be objective interpretation of the situation. Based on the above described, today's The Anthropology of Music cleared racial prejudice and ethnocentrism view, 
exploring different social groups and cultural co-existence. On the basis of ethnic, cultural equality, the research demands of different ethnic groups and cultural diversity. On the basis of traditional music, folk theory content critical reflection on the cultural consensus of people looking for each family member between behavior. In China, The Anthropology of Music on the one hand influenced Ethnomusicology theory and method, it also developed close ties with Chinese traditional music, as well as China's reform and opening up and its change in consciousness is inextricably contact [11]. This fact leads to the study of The Anthropology of Music unprecedented changes in perceptions on. Chinese people of various disciplines Ethnomusicology, Music Culture, The Anthropology of Music, music ethnology and so an unprecedented study of Chinese traditional musical concept study conducted impartial and objective criticism. This new concept of our understanding not only of academic thought, philosophy has changed, but also make our The Anthropology of Music Studies, field of vision broader, more diversified approach, theoretical logic clearer.

\section{Difference on Discipline Methodological Level}

As scholars of music theory and Reconstruction Studies reflection, analysis techniques and research to learn music the way music has been involved as a mature discipline methodology by academic attention. As Ethnomusicology Musicology domain and The Anthropology of Music, in addressing the cultural aspects of music has an irreplaceable role in other disciplines. However, as a new subject of Ethnomusicology and The Anthropology of Music in disciplinary methodological level also has its own characteristics and discipline home. Therefore, from the perspective of disciplinary methodology to examine Ethnomusicology and The Anthropology of Music is not the students in mathematical logic, to build academic unique musical and cultural integration view, relative concept, the basic concepts of Cape same concept, overall concept, adapt and outlook, grasp Ethnomusicology and The Anthropology of disciplinary nature, structure, form and characteristics of Music, the subject of the future development of musicology has quite important.

Subject is academic classification, natural science, social science two knowledge systems (also third of the natural, social and human is said) the concept of a collection of inside knowledge subsystem is an academic concept and knowledge linked. Methodology is people what kind of approach, methods and techniques to observe things deal with the problem is that people understand the world, the general method of transformation of the world. Disciplinary research methodology refers to a domain (subject) of research tasks, research object, research methods, characteristics, purpose and so what kind of a methodological approach to solve with this methodology as a guide to understanding discipline Study subjects and disciplines that will be derived for the methodology. In fact, discipline is a common methodology used in the specific context of the doors of social and academic guidance classification, the sum of principles, theories, methods and means, is classified in a particular area of academic knowledge in this field, research in this area general method. As an interdisciplinary domain of Ethnomusicology and the Anthropology of Music, although there are a lot of similarities in the research methods and objects, but because of the theoretical logic is different from the subject methodology perspective, there are still huge differences. as Professor Du Yaxiong said "within the meaning of these terms is actually a very close relationship, almost the same range of research disciplines, but because they emphasize different focus plane and the names are different, so in fact they are not exactly the same purpose. "[12]

Fieldwork is The Anthropology of Music and Ethnomusicology are insurmountable discipline Research Method. To get as detailed scientific information in person through field practice survey, is The Anthropology of Music and Ethnomusicology common features. Since anthropologist Malinowski proposed the establishment of child work in the fields and the development of theory and method of "participant observation", requiring anthropologists study the existing music activities, but also actually possible to participate in the musician's life way to get first-hand information and experience music [13]. Methodology The subject immediately home by the Ethnomusicology The Anthropology of Music and great esteem. Whether horizontal classification form (micro music survey, the geographical division of music survey, ethnic divisions music survey) or longitudinal survey methods (the nature of the purpose of the field survey as the basis to obtain 
material properties by field surveys conducted longitudinal surveys Classification, usually can be divided into music blog survey, the music topic survey) [14], both of which regard the law as a discipline Fieldwork main research methods. However, due to the different theoretical logic, their fieldwork is very different from the outset. For example, in the field of survey preparation phase, Ethnomusicology pay more attention to focus on the music of the body, like the sound image description, melodies, musical form, at a time, strength, texture and music system, musical styles, music genres, variety, etc. analysis, more attention from starting a cultural group, tribe or folk music research to understand the entire form of music and music system, but it is the only culture to interpret as a background. By contrast, in the fieldwork, The Anthropology of Music pay more attention to research on things like music behind embodied culture. The Anthropology of Music as a family, in the field of inspection, which takes culture as the ultimate destination of their own research. Music is just a symbol, culture music is their maps under the stuff of dreams. In practice, The Anthropology of Music home more attention is to describe the music culture music things like mapping under the words of description, a digital description, geographic area, language, region, ethnic diaspora, villages, suburbs, cities become their concerns focus. It pays more attention to the importance of musical sound itself under the mapping of cultural connotations. Professor Luo Qin in "Introduction to the Theory and Methods of Musicology," the article said: "The five-line note or Gongche spectra recorded music notation, musical tone or accent is Constructivism, music, music or modern music is sound media, music all material combinations are also just music carrier. and the music has become an important integral part of human life and the true source of the content and culture. [15] the Anthropology of Music for its elaboration can be seen out, people and culture is the core of the Anthropology of Music in fieldwork, researchers mapped at things like music and culture is the Anthropology of Music ultimate destination is easy to see, in the Anthropology of Music and Ethnomusicology of fieldwork, culture and music are both working in the fields of content can not be ignored, but they focus on fieldwork that: Ethnomusicology pay more attention to study music system, more attention to the investigation and study of music and musical works and " musical sound "itself, the Anthropology of Music people pay more attention to research and culture, pay more attention to things like music and people as the main manipulators of musical activity musical practice for the content of people and culture.

Synchronic and diachronic respectively are from static and dynamic, horizontal and vertical dimensions of the social structure and morphological study of perspective. The former focuses on the relationship between the elements in a particular socio-economic system and motion system is to grasp the basis of the social structure; the latter focuses on the law to the process of social and economic movements in the process of development on the basis of contradictory movement, to grasp social form. Movement manifested by the still, relatively static in perpetual motion. Thus, both synchronic and diachronic unity has dialectical relationship. Ethnomusicology The Anthropology of Music and at the level of time-oriented research can be divided into diachronic and synchronic research studies. But in the face of research focus has their characteristics. Since Ethnomusicology more attention to study the music of the body, from the synchronic point of view of research, Ethnomusicology pay more attention to existing music, mainly focus on the study of existing music, that is a national "existing" music into the national specific natural and social environment, the study of "cultural context of the music," [16] "existing" system of music, like music, that existing music, singing and other forms of synchronic dimension. In contrast, The Anthropology of Music pays more attention to research diachronic level. Because people things like music and cultural studies at the map The Anthropology of Music is the main content, so "restore history", "counter-study" The Anthropology of Music is the time insurmountable bottleneck, diachronic analysis generated continuity become the Anthropology of the primary means of Music studies. In the actual study, not only of the language and its culture itself is diachronic, and research The Anthropology of Music production, acceptance and historical continuity is diachronic. In fact, The Anthropology Ethnomusicology and the actual investigation and study things like the music during the Music of, and common ideas about the last time when in his study are involved, but because of Ethnomusicology pay more attention to study music system, the synchronic concept of 
time is more important. The Anthropology of Music and people pay more attention to cultural interpretation, so more research oriented diachronic.

Obviously, the subject methodology is an integral part of the development of discipline. Fieldwork and from diachronic Synchronic perception of time and other disciplines and methodological level of Ethnomusicology The Anthropology of Music analyze and study two different purport and focus is extremely important. Mr. Silk and Bamboo in a recent summary of the pros and cons of Ethnomusicology, think of Ethnomusicology sector has "lost standard, cutting off blood," "Western parent, origin avoidance" and "music form, the body digestion" three issues. [17] In my view, this goes to show that The Anthropology of Music and more focused study of human culture, and pay more attention to the music Ethnomusicology System.

\section{References}

[1] Luo Qin. Ethnomusicology, or The Anthropology of Music-- On the subject of translation problems and understanding the "Resolution" and select [J]. Music of 2012 (5): 49-60

[2] Du Yaxiong. Ethnomusicology " $\neq$ " The Anthropology of Music [J]. Chinese Music (Quarterly) 2009 (3): 38-43

[3] Henry Louis Morgan. Ancient Society [M]. Zhang Kurihara, M. Beijing: People's Literature Publishing House .1957: Summary 2

[4] Gothic Benedict Anderson. Imagined Communities: Origin and Spread of Nationalism [M] Shanghai People's Publishing House Wu Rui who translated 2003: Introduction

[5] [6] [7] Eric Hobsbawm. Nations and Nationalism [M]. Li Jinmei Translation Shanghai People's Publishing House 2000: 2

[8] [9] Wu Guodong. Introduction to Ethnomusicology [M]. Beijing: People's Music Publishing House. 2004: 28; 17

[10] Bruno $•$ Nettle. Ethnomusicology Theory and Methods [M]. Samson a translation Taipei: Taipei Book Review Bibliography Press 1964: 23-28

[11] [13] [15] [17] Luo Qin. The Anthropology of Music Theory and Methods Introduction to [M] Shanghai: Shanghai Conservatory of Music Publishing .2011: 43; 3; 17; 3

[12] Liao Mingjun. relationship between music and culture, what - Qin Luo Interview [J]. National Art 2001 (2): 44-59

[14] Melilla Mariam. The Anthropology of Music [M]. Mu Ming Qian interpret Road School Beijing: People's Music Publishing House 2010: 13

[16] Du Yaxiong. Ethnomusicology Introduction to [M]. Shanghai: Shanghai Conservatory of Music Publishing .2011: Introduction 2; 5. 